\title{
COMPARATIVE EVALUATION OF EFFICACY OF ORAL KETAMINE IN DIFFERENTIAL DOSES AS PREMEDICATION IN CHILDREN
}

\author{
Elango Pachaimuthu1, Sivakumar Gurusamy², Balasubramaniaguhan Vivekanandan ${ }^{3}$, Anitha Krishanmurthi', Srinivasan Anbu ${ }^{5}$ \\ ${ }^{1}$ Associate Professor, Department of Anaesthesiology, KAP Viswanatham Government Medical College, Tiruchirapalli. \\ ${ }^{2}$ Associate Professor, Department of Anaesthesiology, KAP Viswanatham Government Medical College, Tiruchirapalli. \\ ${ }^{3}$ Assistant Professor, Department of Anaesthesiology, KAP Viswanatham Government Medical College, Tiruchirapalli. \\ ${ }_{4}^{4}$ Assistant Professor, Department of Anaesthesiology, KAP Viswanatham Government Medical College, Tiruchirapalli. \\ ${ }_{5}^{5}$ Associate Professor, Department of Orthopaedics, KAP Viswanatham Government Medical College, Tiruchirapalli.
}

\section{ABSTRACT}

\section{BACKGROUND}

Premedication traditionally has several goals; Reduction of anxiety and fear, secretion and provision of basal or background sedation. The primary purpose of prescribing drugs in the immediate preoperative period is to allay patient anxiety. In this study ketamine was evaluated as an oral premedication agent. The effect of different dosages of ketamine and its advantages and disadvantages were studied.

\section{MATERIALS AND METHODS}

In this prospective, randomized and double blind study, hundred children posted for lower abdominal and perineum surgeries. The patients were randomly divided into two Groups. Group I received $4 \mathrm{mg} / \mathrm{Kg}$ and Group II received $6 \mathrm{mg} / \mathrm{Kg} 30-40 \mathrm{~min}$ before surgery. All children were evaluated the onset and level of sedation, emotional state, reaction to separation from parents and mask application for induction of anaesthesia, side effects. The observation was analysed using student's T test and Chi-square test used to compare the data between two groups.

\section{RESULTS}

The oral ketamine can be used as a better premedication drug to produce optimal sedation and emotional state.

\section{CONCLUSION}

Oral ketamine $6 \mathrm{mg} / \mathrm{Kg}$ has been shown to be an effective and safe agent for premedication of children undergoing elective surgeries.

\section{KEYWORDS}

Anaesthesia, Premedication, Paediatrics, Oral Ketamine, Sedatives.

HOW TO CITE THIS ARTICLE: Pachaimuthu E, Gurusamy S, Vivekanandan B, et al. Comparative evaluation of efficacy of oral ketamine in differential doses as premedication in children. J. Evolution Med. Dent. Sci. 2017;6(9):704-709, D0I: $10.14260 /$ Jemds/2017/152

\section{BACKGROUND}

Premedication can mean any drug given to a patient prior to introduction of anaesthesia; it is traditionally used to refer to drugs given some finite time before

The induction, and usually in the ward before coming to the operation theatre. 1

The fashions of medicine fluctuate and such fashions have affected premedication, not only in the type and amount of premedication but even in its use also.

The term premedication was first used in 1920s. Premedication should decrease anxiety without producing excessive drowsiness, provide amnesia for the perioperative period while maintaining co-operation prior to loss of consciousness, ${ }^{2}$ Relieve the pre-operative pain if present, Secondary goals include reduction in the requirement of anaesthetic agents, Minimizing the undesirable effects of

Financial or Other, Competing Interest: None.

Submission 16-12-2016, Peer Review 14-01-2017,

Acceptance 21-01-2017, Published 30-01-2017.

Corresponding Author:

Dr. Elango Pachaimuthu,

D 49, Tenth Cross West,

Thillai Nagar, Trichy-620018.

E-mail: narmadha18@yahoo.com

DOI: $10.14260 /$ jemds $/ 2017 / 152$ anaesthetic agents., Reducing the volume \& acidity of gastric juice, may help to reduce the stress response in the perioperative period, to reduce the possibility of awareness during light anaesthesia. The ideal premedication: Would be easily administered, well accepted by the patients, must act rapidly, should not prolong emergence from anaesthesia, must have few side effects. ${ }^{3}$

Ketamine is a phencyclidine derivative with potent analgesic properties which has gained popularity as a sole intravenous anaesthetic for a short surgical procedure. Ketamine was introduced as a premedication in children by HOWARD B GUSTEIN (1992) in C. S. Moth Children Hospital.11 Oral premedication has certain advantages and disadvantages.

This study was done to assess the efficacy of oral ketamine as a premedication in children for elective surgeries of intermediate duration and to compare the different dosage schedules, emotional state, painless intravenous cannulation and reaction to separation from parents. ${ }^{4}$

The goal of the premedication in paediatric surgery is the safe induction of anaesthesia in the paediatric patient with a minimum stress and risk for the children. However, the paediatric patient differs from the average adult who desires primarily, lack of recall [Amnesia] and relief of anxiety [Anxiolysis]. Children's anxiety may focus on major issues 
such as separation from parents, fear of needles, a concern of change in bodily image or not awakening at the of an anaesthetic [Death] or secondarily minor issues such as taste or odour of medication and size of tablets and capsules. ${ }^{5}$

The anaesthesiologist caring for child primarily interested in minimizing potential risk factors during the anaesthetic may be more concerned about the decrease in vagal activity, vomiting and aspiration, prevention of secretion, medication overdose and respiratory depression as a result of a premedication and assessment of an acceptable airway. ${ }^{6}$

Administration of premedication in children, the four principles need to be addressed, children fear of needles and intensely dislike injections, it is essential that the anaesthesiologist deal openly and honestly with the child's fear and concerns, timing of the premedication is essential. ${ }^{7}$

\section{MATERIALS AND METHODS}

A Double blind prospective randomized study was done to evaluate the efficacy of oral ketamine in various dosages as a premedication in children.

The clinical study was carried out in hundred children who came to Government Rajaji Hospital, Madurai for surgeries in lower abdomen and perineum, [approximately 30-45 minutes, duration] in the year of 1995-97. The age group of children selected for this study was 1-10 years and who weigh between 5-25 Kgs. Only patients belonging to ASA I and II were chosen to avoid the influence of the associated diseases on the observation. Patients on other sedatives, neuroleptics and barbiturates were excluded from the study for fear of their possible influence on their effects of the premedication drug. Preanaesthetic evaluation was done prior to study by history, clinical examination, relevant investigation $\mathrm{Hb}$, urine analysis, bleeding time, clotting time and if needed serum electrolytes, blood urea and blood sugar and obtained informed consent.

The anaesthetic procedure and the surgery were discussed. All the children were anaesthetized in sequence of preoxygenation, Induction with Thiopentone and atropine, intubated by using depolarizing muscle relaxant suxamethonium, maintained with $\mathrm{N}_{2} \mathrm{O}, \mathrm{O}_{2}$ and Halothane.

Preoperative apprehension was assessed as marked, moderate, slight, nil. The children were divided into 2 groups randomly as per premedication given.

Group I- 4 mg of ketamine per Kg of body weight.

Group II- $6 \mathrm{mg}$ of ketamine per Kg of body weight.

The test drugs were administered $30-40$ min prior to surgery. Preservative free ketamine hydrochloride used as an oral premedication. It has a strength of $50 \mathrm{mg}$ per $\mathrm{ml}(2 \mathrm{ml}$ ampoules). The drug was mixed with soft, sweetish drink 'Bovonto' (From Kalimark Company). The total value of mixture was $0.2 \mathrm{ml} / \mathrm{Kg}{ }^{8}$ The drug administered through the mouth after getting consent from the older children and from mother of smaller children. The drug was mixed by an anaesthesiologist who was not observing the patient for the study or actually performing the anaesthesia. The time between premedication and the first assessment of the effect of the premedication was 5 minutes and assessed every 5 minutes for 30-40 minutes. All the children were monitored with use of a pulse oximeter and blood pressure cuff at the time of administration and every 5 minutes after administration, thereafter throughout the study. Heart and respiratory rates were monitored at the same intervals. Respiratory rate was counted at each time interval and children were observed for the signs of upper airway obstruction. The times of onset of sedation were recorded. Sedation was graded by evaluating the child's appearance with the help of sedation scale described as below.

\section{Sedation Scale}

1. Barely arousable; asleep; need shaking or shouting to arouse.

2. Asleep; eyes closed; arouse with soft voice, light touch.

3. Sleepy: Eyes open but less active and responsive.

4. Awake.

5. Agitated.

We observed each patient's level of consciousness, emotional state and acceptance of the ketamine solution at time of administration, then we observed the patient for the loss of response to name or conversation, reaction to separation from parents and the presence of side effects were assessed by using emotional scale.

\section{Emotional Scale}

1. Calm.

2. Apprehensive; not smiling; tentative behaviour, withdrawn.

3. Crying

4. Thrashing; crying with movement of arms legs resistance.

As soon as a stable level of sedation was observed, children were transferred to the operating room and anaesthesia was induced by anaesthesiologist not involved in observing the child for the study or making the premedication, if the sedation did not occur within 30-40 minutes of administration of the premedication, the child was transferred to the operating room and anaesthesia was induced with $\mathrm{N}_{2} \mathrm{O}: \mathrm{O}_{2}$ and Halothane. In sedated children, intravenous cannulation was attempted once before induction of anaesthesia and the child's response was recorded. In all children, prior to induction preoxygenation was done for 3 minutes through face mask. The child's acceptance of face mask was recorded. After intravenous cannulation inj. Thiopentone $5 \mathrm{mg} / \mathrm{Kg}$ and atropine 0.02 $\mathrm{mg} / \mathrm{Kg}$ for induction followed by inj. suxamethonium 1-2 $\mathrm{mg} / \mathrm{Kg}$ were given to facilitate tracheal intubation. Secretion at the time of intubation was graded by the anaesthesiologist as secretion scale.

\section{Secretion Scale}

1. Decreased.

2. Normal.

3. Increased.

And any occurrence of laryngospasm was recorded as a yes or no response. During course of the anaesthesia, the halothane concentration was maintained at which sign of light anaesthesia could be avoided.

In the recovery room, patients were observed for emergence phenomena, time to responsiveness, incidence of nausea and vomiting and need for airway support. We recorded blood pressure, heart and respiratory rates, $\mathrm{SpO}_{2}$ at 
15 minutes intervals. We also recorded the time of discharge and the patient's emotional state throughout recovery and at discharge from recovery room.

The observation was analysed using student's T test and Chi-square test used to compare the data between the two groups. Data were analysed with one factor analysis of variance for continuous variables (Age, weight, onset of sedation, operative time). Mean values were reported as means+standard derivation. A $\mathrm{P}<0.05$ value indicated statistically significant differences.

\section{RESULTS}

Table I shows the group allotment according to the dosage of oral ketamine used and $\mathrm{Ph}$ of the solution after mixing with $0.2 \mathrm{ml} / \mathrm{Kg}$ of Bovonto [Cola flavoured soft drink]

\begin{tabular}{|c|c|c|}
\hline Groups & I & II \\
\hline Ketamine & $4 \mathrm{mg} / \mathrm{Kg}$ & $6 \mathrm{mg} / \mathrm{Kg}$ \\
\hline $\mathrm{pH}$ of Ketamine Solution & 3.8 & 3.8 \\
\hline $\mathrm{pH}$ of Bovonto & 3.0 & 3.0 \\
\hline Final pH of the Solution & 3.2 & 3.4 \\
\hline \multicolumn{2}{|c|}{ Table I. Group allotment } \\
\hline
\end{tabular}

$\mathrm{pH}$ measured by the Department of Biochemistry MMC Madurai-20, by using Merck $\mathrm{pH}$ indicator paper and confirmed by $\mathrm{pH}$ meter.

The total volume was $0.2 \mathrm{ml} / \mathrm{Kg}$ of body weight. The volume of solution $0.2 \mathrm{ml} / \mathrm{Kg}$ also was chosen to remain below the most conservative residual gastric volume limit of $0.4 \mathrm{ml} / \mathrm{Kg}$ [James et al]. Although $\mathrm{pH}$ of a Bovonto was 3.0 and the $\mathrm{pH}$ of the final mixed solution was 3.2-3.4, the $\mathrm{pH}$ of the solution was 3.2-3.4 greater than the most conservative $\mathrm{pH}$ limit of 2.5 thought to promote lung damage after aspiration of gastric contents [Teabeut JR et al].6,9

\begin{tabular}{|c|c|c|}
\hline Criteria & I (4 mg/Kg) & II (6 mg/Kg) \\
\hline $\begin{array}{c}\text { Duration of } \\
\text { Surgery (Min.) }\end{array}$ & $34.4 \pm 16.67$ & $37.7 \pm 21.91$ \\
\hline \multicolumn{3}{|c|}{ Table II. Demographic } \\
profile of the patients
\end{tabular}

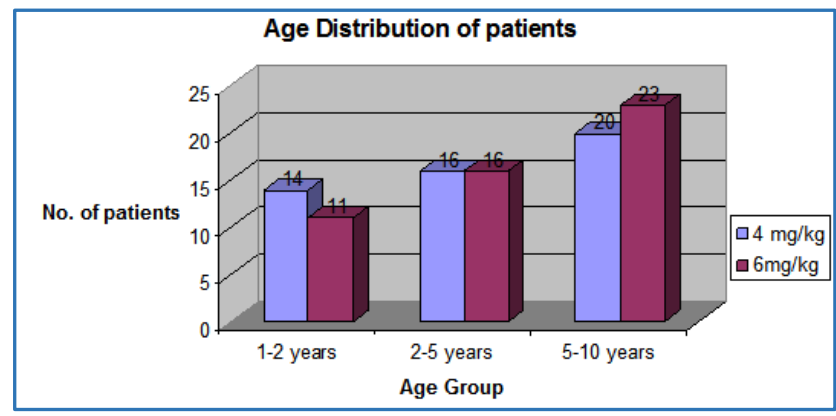

Figure 1. Age distribution of patients

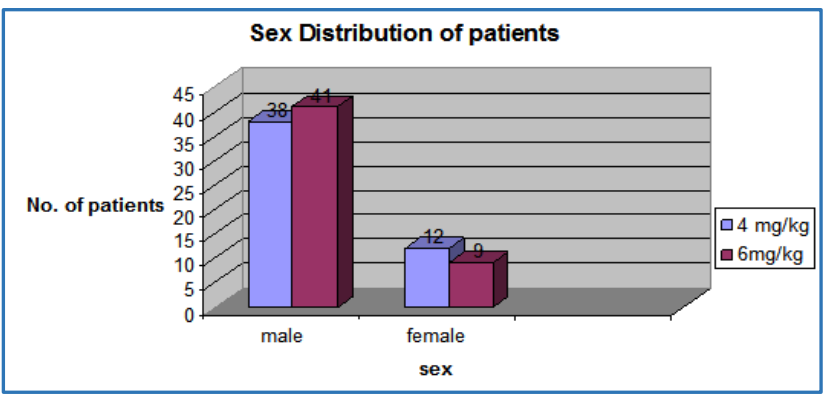

Figure 2. Sex Distribution

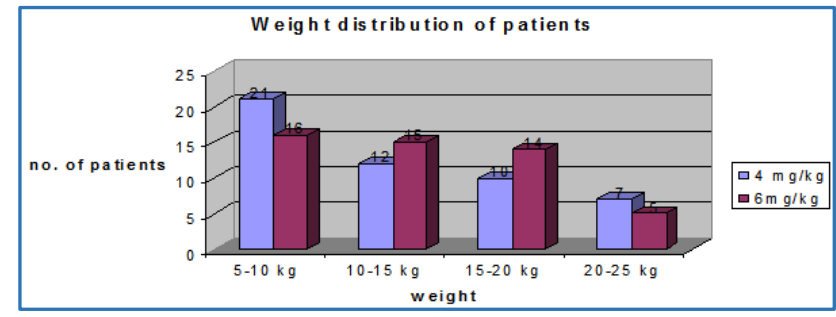

Figure 3. Weight distribution

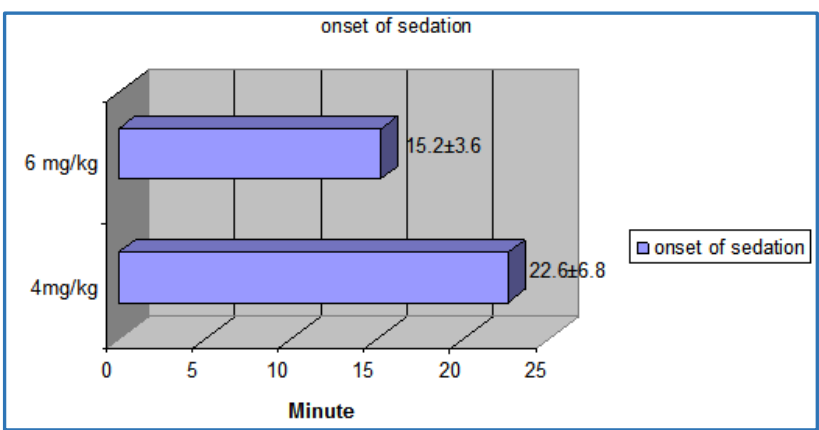

Figure 4. Onset of sedation

All the values are mean standard deviation except sex criterion. The two groups were comparable age, sex, weight and duration of surgery.

\begin{tabular}{|c|c|c|c|}
\hline No. & Surgical Procedure & $\begin{array}{l}\text { Group A } \\
4 \mathrm{mg} / \mathrm{Kg} \\
\end{array}$ & $\begin{array}{l}\text { Group B } \\
6 \mathrm{mg} / \mathrm{Kg} \\
\end{array}$ \\
\hline 1 & Herniotomy & 16 & 16 \\
\hline 2 & Excision of sac & 3 & 10 \\
\hline 3 & Circumcision & 6 & 14 \\
\hline 4 & Orchidopexy & 3 & 2 \\
\hline 5 & $\begin{array}{l}\text { Hypospadias } \\
\text { Correction }\end{array}$ & 7 & 1 \\
\hline 6 & $\begin{array}{c}\text { Umbilical Hernia } \\
\text { Repair }\end{array}$ & 2 & 1 \\
\hline 7 & $\begin{array}{l}\text { Post Urethral Value } \\
\text { Endoscopic } \\
\text { Fulguration } \\
\end{array}$ & 1 & 1 \\
\hline 8 & Rectal polypectomy & 2 & 2 \\
\hline 9 & Colostomy Closure & 1 & 1 \\
\hline 10 & $\begin{array}{c}\text { Cyst Excision } \\
\text { (Sebaceous, } \\
\text { Cysticercosis, } \\
\text { Dermoid) } \\
\end{array}$ & 4 & 2 \\
\hline 11 & $\begin{array}{c}\text { Anal Surgery (Internal } \\
\text { Sphincterotomy } \\
\text { Transposition, } \\
\text { Fistulectomy) }\end{array}$ & 4 & - \\
\hline 12 & Corn foot & 1 & - \\
\hline 13 & $\begin{array}{c}\text { Urethral stricture } \\
\text { dilatation }\end{array}$ & 1 & - \\
\hline & Total & 50 & 50 \\
\hline
\end{tabular}

Table III. Surgical procedure performed in the two groups

\begin{tabular}{|c|c|c|c|}
\hline Criterion & $\begin{array}{c}\text { Group I } \\
\mathbf{4} \mathbf{~ m g}\end{array}$ & $\begin{array}{c}\text { Group II } \\
\mathbf{6 ~} \mathbf{~ m g}\end{array}$ & P Value \\
\hline Onset of sedation & $22.6 \pm 6.8$ & $15.2 \pm 3.6$ & $<0.001$ \\
\hline \multicolumn{4}{|c|}{ Table IV. Comparison of different doses of ketamine } \\
\hline
\end{tabular}

All values are mean \pm standard deviation. 
$* \mathrm{P}$ value $<0.05$ is taken as statistically significant. It was seen that increasing the dose of oral ketamine significantly after the onset of time.

\begin{tabular}{|c|c|c|c|c|}
\hline Criterion & $\begin{array}{c}\text { Group I } \\
4 \mathrm{mg} / \mathrm{Kg}\end{array}$ & $\begin{array}{l}\text { Group II } \\
6 \mathrm{mg} / \mathrm{Kg}\end{array}$ & $\begin{array}{c}\mathrm{X} 2 \\
\text { value }\end{array}$ & $\begin{array}{c}P \\
\text { value }\end{array}$ \\
\hline $\begin{array}{l}\text { Successful (Painful) } \\
\text { IV Cannulation }\end{array}$ & $58 \%$ & $86 \%$ & 10.2 & $<0.005$ \\
\hline $\begin{array}{l}\text { Calm Reaction to } \\
\text { Mask Application }\end{array}$ & $26 \%$ & $54 \%$ & 8.21 & $<0.005$ \\
\hline Emotionally Calm & $84 \%$ & $88 \% 5$ & 0.32 & $<0.5$ \\
\hline Sedation & $82 \%$ & $92 \%$ & 2.2 & $<0.5$ \\
\hline
\end{tabular}

It was observed that $6 \mathrm{mg} / \mathrm{Kg}$ of body weight group had the increased percentage of painless IV cannulation, no resistance to mask application, emotionally calm and sedated

\begin{tabular}{|c|c|c|c|}
\hline $\begin{array}{l}\text { Sl. } \\
\text { No. }\end{array}$ & Grade & $\begin{array}{c}\text { Group I } \\
4 \mathrm{mg} / \mathrm{Kg}\end{array}$ & $\begin{array}{l}\text { Group II } \\
6 \mathrm{mg} / \mathrm{Kg}\end{array}$ \\
\hline 1 & $\begin{array}{c}\text { Barely } \\
\text { Arousable }\end{array}$ & 7 & 15 \\
\hline 2 & Asleep & 26 & 23 \\
\hline 3 & Sleepy & 7 & 7 \\
\hline 4 & Awake & 9 & 5 \\
\hline 5 & Agitated & 1 & - \\
\hline
\end{tabular}

\begin{tabular}{|c|c|c|c|}
\hline $\begin{array}{l}\text { Sl. } \\
\text { No. }\end{array}$ & Grade & $\begin{array}{c}\text { Group I } \\
4 \mathrm{mg} / \mathrm{Kg}\end{array}$ & $\begin{array}{l}\text { Group II } \\
6 \mathrm{mg} / \mathrm{Kg}\end{array}$ \\
\hline 1 & Calm & 42 & 44 \\
\hline 2 & Apprehensive & 7 & 6 \\
\hline 3 & Crying & 0 & 0 \\
\hline 4 & Thrashing & 1 & 0 \\
\hline
\end{tabular}

It was applicable to emotional state of children given premedication and separation reaction from parents. It shows $6 \mathrm{mg} / \mathrm{Kg}$ group had good statistically significant results.

\begin{tabular}{|c|c|c|c|c|c|}
\hline $\begin{array}{c}\text { Sl. } \\
\text { No. }\end{array}$ & Effects & $\begin{array}{c}\text { Group I } \\
\mathbf{4} \mathbf{~ m g} / \mathbf{K g}\end{array}$ & $\begin{array}{c}\text { Group II } \\
\mathbf{6} \mathbf{~ m g} / \mathbf{K g}\end{array}$ & $\begin{array}{c}\mathbf{X}^{\mathbf{2}} \\
\text { value }\end{array}$ & $\begin{array}{c}\text { P } \\
\text { value }\end{array}$ \\
\hline 1 & Nystagmus & $14 \%$ & $28 \%$ & 2.4 & $<0.5$ \\
\hline 2 & Limb Movements & $4 \%$ & $6 \%$ & 0.2 & $>0.5$ \\
\hline 3 & Vomiting & $2 \%$ & $4 \%$ & 0.34 & $>0.5$ \\
\hline 4 & $\begin{array}{c}\text { Secretion at the } \\
\text { Time of Intubation }\end{array}$ & $14 \%$ & $36 \%$ & 6.4 & $<0.02^{*}$ \\
\hline \multicolumn{6}{|c|}{ Table VIII. Side effects [Number of patients] } \\
\hline
\end{tabular}

It was shown that $6 \mathrm{mg} / \mathrm{Kg}$ body weight shows increased incidence of side effects than $4 \mathrm{mg} / \mathrm{Kg}$ but all were not very significant except secretion at the time of intubation and Nystagmus.

Following premedication systolic blood pressure and heart rate remained stable in each group. Respiratory rate decreased minimally following premedication in both groups and no child complained of vivid or unpleasant dreams in the perioperative period. 5 out of 50 children did notice the ketamine taste.

There was no fall of arterial $\mathrm{O}_{2}$ saturation of blood.

\begin{tabular}{|c|c|c|c|c|c|c|}
\hline \multirow{3}{*}{ Parameters } & \multicolumn{6}{|c|}{ Premedication } \\
\hline & \multicolumn{3}{|c|}{$4 \mathrm{mg} / \mathrm{Kg}$} & \multicolumn{3}{|c|}{$6 \mathrm{mg} / \mathrm{Kg}$} \\
\hline & Before & After & $\begin{array}{c}\mathbf{P} \\
\text { value }\end{array}$ & Before & After & $\begin{array}{c}P \\
\text { Value }\end{array}$ \\
\hline Pulse Rate & $\begin{array}{c}109.89 \pm \\
8.81\end{array}$ & $\begin{array}{c}100.44 \pm \\
10.02\end{array}$ & $<0.0001$ & $\begin{array}{c}116.92 \pm \\
10.16\end{array}$ & $\begin{array}{c}102.56 \pm \\
9.60\end{array}$ & $<0.001$ \\
\hline $\begin{array}{c}\text { Respiratory } \\
\text { Rate }\end{array}$ & $\begin{array}{l}22 \pm \\
1.49\end{array}$ & $\begin{array}{l}20 \pm \\
1.49\end{array}$ & $>0.1$ & $\begin{array}{c}21.92 \pm \\
1.9\end{array}$ & $\begin{array}{c}19.04 \pm \\
1.32\end{array}$ & $>0.01$ \\
\hline $\mathrm{SpO}_{2}$ & $\begin{array}{l}97.8 \pm \\
0.84\end{array}$ & $\begin{array}{c}98.36 \pm \\
0.46\end{array}$ & $<0.001$ & $\begin{array}{c}98.02 \pm \\
0.7\end{array}$ & \begin{tabular}{|c|}
$98.06 \pm$ \\
0.6
\end{tabular} & $<0.001$ \\
\hline Systolic BP & $\begin{array}{c}90.76 \pm \\
10.38\end{array}$ & $\begin{array}{c}92.68 \pm \\
10.94\end{array}$ & $<0.001$ & $\begin{array}{c}101.56 \pm \\
8.92\end{array}$ & $\begin{array}{c}101.76 \pm \\
9.4\end{array}$ & $>0.1$ \\
\hline & le IX & hanae & & aram & ers & \\
\hline
\end{tabular}

The values are mean \pm standard deviation.

$P$ value of $<0.05$ was taken as statistically significant. There was no significant change in pulse rate, respiratory rate and oxygen saturation.

\section{DISCUSSION}

In this study ketamine was evaluated as an oral premedication agent. The effect of different dosages of ketamine and its advantages and disadvantages were studied.

Premedication traditionally has several goals; reduction of anxiety and fear, secretion and provision of basal or background sedation. Of these the primary purpose of prescribing drugs in the immediate preoperative period is to allay patient anxiety. Premedication also helps to prevent adverse reactions of the autonomic nervous system beginning even before induction of anaesthesia. Anaesthesia and surgery constitute great psychic stress in any patient. The overall frequency of anxiety before anaesthesia is 40 $60 \%$ of older children [Norris and David 1967] using an extensive psychological questionnaire as many as $80 \%$ of patients were anxious [Corman et al 1958]. A greater frequency has been found in females than in males.

The purpose of the study was to compare the onset of sedation, quality of sedation, grade of emotional state and adverse effects associated with increasing dosage of oral ketamine. Premedication was considered necessary, as a pilot study using unpremeditated patients resulted in an unaccepted frequency of vasovagal attacks following lumbar puncture. ${ }^{10}$ Some of the pilot study shows children who were given premedication show better value of arterial oxygen saturation than unpremedicated anxious apprehensive children. ${ }^{1}$ Relief of apprehension may reduce the minimum effective dose of anaesthetic agents \{Male et al\}. Sedation has been considered a useful property of premedication drug. (Collins 1976).

There is no entirely satisfactory way to ensure smooth induction of children. The ideal premedication would be easily administered, well accepted, act rapidly, not prolong emergence from anaesthesia and have few side effects. This study is to concurrently examine these attributes and level of sedation, separation reaction, preoperative and postoperative emotional state, amnesia, acceptance of technique and evidence of side effects after oral administration of ketamine to young children. Almost all drugs available for preanaesthetic medication require either an injection, administering a pill or nasal or rectal administration of the drug. 
Any of these methods could be difficult or traumatic for 110-year-old children. In addition, many of currently used drug cause respiratory depression and none provide uniform balance of sedation, amnesia and analgesia before surgery (Bartz PL et al 1986).

Only $16 \%$ of ketamine is bioavailable orally as opposed to 93\% in intramuscular or intravenous injection (Grant LS et al 1981). It also has been shown that oral ketamine doses equivalent to intramuscular doses produce peak plasma ketamine concentration only one fifth as high as intramuscularly delivered concentration and the time to reach peak plasma concentration of ketamine. ${ }^{4}$ However, the plasma concentration of nor ketamine, an active metabolite with one third the potency of ketamine is twice as high after oral administration of ketamine (Grant LS et al 1981). ${ }^{11}$ The increased amount of nor ketamine relative to ketamine with oral administration may account for part of the sedative effect observed and possibly reduce the incidence of unwanted side effects. ${ }^{12}$

We decided to use a cola-flavoured soft drink (Bovonto) as the vehicle for ketamine administration because it was easily accepted by children than other liquids. The $\mathrm{pH}$ of the solution was 3.2-3.4 greater than the most conservative $\mathrm{pH}$ limit of 2.5 thought to cause lung damage after aspiration of gastric contents. (James CF et al 1984). The volume of solution, $0.2 \mathrm{ml} / \mathrm{Kg}$ also was chosen to remain below the most conservative residual gastric volume limit of $0.4 \mathrm{ml} / \mathrm{Kg}$ (James CF et al 1984).13 However, some children in the treatment groups did not notice ketamine taste. Use of cola syrup instead of the soft drink might minimize this taste. We decided not to administer oral atropine to reduce secretion because it also imparts a bitter taste and the time to peak ketamine effect (15-22 $\mathrm{min}$ after administration). Oral atropine also delays gastric emptying. The atropine administration prior to ketamine has been shown to increase the frequency of unpleasant dreams. So, we decided to give atropine $0.02 \mathrm{mg} / \mathrm{Kg}$ with induction dose of IV Thiopentone sodium.

In our study, the onset of sedation in $4 \mathrm{mg} / \mathrm{Kg}$ group was $22.58 \pm 6.8$ minutes and the onset of sedation in $6 \mathrm{mg} / \mathrm{Kg}$ group was $15.2 \pm 3.5$ minutes. Howard B et al showed, the children receiving oral ketamine $6 \mathrm{mg} / \mathrm{Kg}$ had $100 \%$ sedation and better emotional state than $3 \mathrm{mg} / \mathrm{Kg}$ oral ketamine group. The incidence of Nystagmus was $3.3 \%$ of patients who received $3 \mathrm{mg} / \mathrm{Kg}$ and $60 \%$ of those given $6 \mathrm{mg} / \mathrm{Kg}$ ketamine. Random limb movements were apparent in $7 \%$ of patients given $3 \mathrm{mg} / \mathrm{Kg}$ and $13 \%$ of those received $6 \mathrm{mg} / \mathrm{Kg}$ ketamine were sedated enough to attempt intravenous cannulation and the oral secretion present at intubation did not differ significantly between the groups receiving $3 \mathrm{mg} / \mathrm{Kg}$ and $6 \mathrm{mg} / \mathrm{Kg} .{ }^{14}$

This study shows the children receiving oral ketamine $6 \mathrm{mg} / \mathrm{Kg}$ had 92\% sedation and $4 \mathrm{mg} / \mathrm{Kg}$ group had 82\% sedation. The $6 \mathrm{mg} / \mathrm{Kg}$ group had better emotional state (88\%) than $4 \mathrm{mg} / \mathrm{Kg}$ group (84\%). $86 \%$ of patients given $6 \mathrm{mg} / \mathrm{Kg}$ ketamine were judged sedated enough to attempt intravenous cannulation before induction of anaesthesia. Induction time was shortened significantly by ketamine (Unpublished observation). The amount of secretion at the time of intubation was 38\% in $6 \mathrm{mg} / \mathrm{Kg}$ group and $14 \%$ those received $4 \mathrm{mg} / \mathrm{Kg}$. The incidence of Nystagmus $28 \%$ and limb movement $6 \%$ of patients who received $6 \mathrm{mg} / \mathrm{Kg}$ and
Nystagmus $14 \%$ and limb movement $4 \%$ of patient who received $4 \mathrm{mg} / \mathrm{Kg} .{ }^{15}$

Incidence of vomiting was reported in two patients who received $6 \mathrm{mg} / \mathrm{Kg}$ and one who received $4 \mathrm{mg} / \mathrm{Kg}$. As per statistics, the only significant disadvantage was increased secretion. 16

In summary, we found that oral administration of $6 \mathrm{mg} / \mathrm{Kg}$ ketamine for paediatric premedication provides rapid onset of satisfactory sedation $(p<0.001)$ with appropriate amnesia and few side effects. The $4 \mathrm{mg} / \mathrm{Kg}$ dose did not provide uniform sedation in all patients and did not provide statistically significant improvement in premeditated emotional state and separation reaction than compared with $6 \mathrm{mg} / \mathrm{Kg}$ group. Children accepted the technique well and parents were satisfied with the outcome. We were able to use this technique effectively in busy government hospitals with the cooperation of our nurses in the preoperative area.

\section{CONCLUSION}

It was concluded from the study that oral ketamine can be used as a better premedication agent to produce optimal sedation and emotional state and can be considered as an alternative drug in busy government hospital. Oral ketamine $6 \mathrm{mg} / \mathrm{Kg}$ has been shown to be an effective and safe agent for premedication of children undergoing elective surgeries.

\section{REFERENCES}

[1] Baker AB. Preoperative medication. Clinics in Anaesthesiology 1986;4:457-79.

[2] Bartez PL, Stanely TLL. Pharmacology of intravenous narcotic anaesthetic. In: Miller RD, ed. Anaesthesia Newyork: Churchill Livingstone 1986:780-95.

[3] Grimes JG. Oral premedication in children. Anaesth Analg 1962;41(2):201-2.

[4] Joshi G, Dave CR. Oral ketamine premedication in paediatric patients. Ind J Anaesth 1994;42:342.

[5] Greenberg JA, Davis PJ. Premedication and induction of anaesthesia in paediatrics surgical patients. Anaesthesiology Clinics of North America 1996;14(1):781-802.

[6] Morrison JE Jr, Lockhort CH. Preoperative fasting and medication in children. Anaesthesiology clinic of North America 1991;9(4):731-743.

[7] Morgan AJ, Dutkiewicz TWS. Oral ketamine. Anaesthesia 1983;38(3):293.

[8] Raidoo DM, Rocke DA, Brock-Utne JG, et al. Critical volume for pulmonary aspiration: reappraisal in a primate model. Br J Anaesth 1990;65(2):248-250.

[9] Teabeaut JR. Aspiration of gastric contents: an experimental study. Am J Pathol 1952;28(1):51-67.

[10] Beeby DG, Hughes JO. Behaviour of unsedated children in the anaesthetic room. Br J Anaesth 1980;52(3):27981.

[11] Grant IS, Nimmo WS, Clements JA. Pharmacokinetic and analgesic effects of i.m and oral ketamine. $\mathrm{Br} \mathrm{J}$ Anaesth 1981;53(8):805-10.

[12] Hain WR. Oral ketamine. Anaesthesia 1983;38(8):8101.

[13] James CF, Modell JH, Gibbs CP, et al. Pulmonary aspiration--effects of volume and $\mathrm{pH}$ in the rat. Anaesth Analg 1984;63(7):655-8. 
[14] Sadove MS, Shulman M, Hatano S, et al. Analgesic effect of ketamine administered subdissociative doses. Anaesth Analg 1971;50(3):452-7.

[15] Stewart KG, Rowbottom SJ, Aitken AW. Oral ketamine premedication for paediatric cardiac surgery-a comparison with intramuscular morphine (both after oral trimeprazine). Anesth Intensive Care 1990;18(1):11-14.
[16] Liang HS, Liang HG. Minimizing emergence phenomena: sub dissociate dosage of ketamine in balanced surgical anaesthesia. Anaesth Analg 1975;54(3):312-6. 